\title{
War and Capitalism: Some Important Theories and a Number of Relevant Facts
}

\author{
João Carlos Graça \\ Professor of Sociology, ISEG - Lisbon School of Economics and Management \\ Researcher, SOCIUS - Research Centre in Economic and Organizational Sociology, University of Lisbon \\ Address: Rua Miguel Lupi 20, Gabinete 213, 1249-078 Lisbon, Portugal \\ E-mail: jgraca@iseg.ulisboa.pt \\ Rita Gomes Correia \\ Researcher, SOCIUS - Research Centre in Economic and Organizational Sociology, University of Lisbon \\ Address: Rua Miguel Lupi 20, Gabinete 213, 1249-078 Lisbon, Portugal \\ E-mail: ritagomescorreia@yahoo.com
}

\begin{abstract}
The first thing worth noting about "war and capitalism" are the important intellectual traditions referring to the relations between these two terms, which operate in radically opposing ways. However, the main intellectual currents since the Enlightenment have posited an essential antipathy between these two concepts. Economic links were supposed to inhibit social conflicts and promote reciprocal dependencies, thus civilizing customs and promoting peace, both internally and among different sovereign entities. These ideas are coherent with world-visions with many ramifications, but often expressed under the form of an "oughtto-be", not regarding real facts. An example is the work of Adam Smith, who argued that colonial trade was potentially a peaceful activity, good for all parties involved, whereas he simultaneously recognized that economic reality strayed considerably from such a rosy picture. The exact reasons for that remained somewhat vague, although Smith tended to blame monopolies and the mingling of trade with the exercise of sovereignty, as opposed to a peaceinducing model of open competition. This cluster of issues is treated here via the revision of the correspondent ideas by a number of important social theorists, including Adam Smith, Karl Marx, Max Weber, Werner Sombart, Thorstein Veblen, Joseph Schumpeter, Alexander Gerschenkron, Karl Polanyi, Fernand Braudel, Giovanni Arrighi and Michael Mann. The theories advanced by these authors are also contrasted with various important historical facts and trends, mentioned in the works of other relevant researchers, mostly historians, suggesting the convenience of keeping an open mind vis-à-vis the complexities, ambivalences and indeterminacies of social realities.
\end{abstract}

Keywords: war, capitalism, cycles of hegemony, pluralism in sociological approach, complexity of historical realities, novelty and continuities in international relations

There are a number of important aspects immediately worth noting about "war and capitalism." The first is the deeply heterogeneous nature of this conjunction. Another is the presence of important intellectual traditions regarding the relations between these two ideas, operating in very different, radically opposing ways.

\footnotetext{
(C) João Carlos Graça, 2015

(C) Rita Gomes Correia, 2015

(C) Russian Sociological Review, 2015
}

DOI: $10.17323 / 1728-192 \mathrm{X}-2015-4-92-114$ 


\section{The Theories}

Leading philosophical currents in Europe since the Enlightenment have mostly argued for a negative correlation, even an essential antipathy, between these two concepts and the realities so denoted. The tendency in this case is to proceed based on the doux commerce model, i.e. economic links would supposedly inhibit social conflict and promote reciprocal dependencies, the convergence of interests, and more broadly the affinity of sensibilities, inclinations and mentalities, contributing to the "civilization of customs" and peace: both peace among different sovereign entities, and civil peace and social harmony within each State (see Elias [2000] and Hirschman [1997]).

Such views are coherent with world-visions implying many ramifications. Moreover, judgments are often set out under the form of an "ought-to-be," not regarding actual situations. For example, Adam Smith (1999) argued that colonial trade was a potentially peaceful activity and good for all parties involved - the various European powers and the populations of colonial territories-but he recognized that reality strayed considerably from this rosy picture. Actual commercial activities were often based on prey, enslavement, secrecy, deception and generally on violent and harmful practices. However, Smith added, this was only circumstantial, without any logical necessity uniting the various terms, in fact quite the opposite: if violence and deception were connected with trade, that was because it occurred as a monopoly, using chartered companies and mixed with the exercise of sovereignty. If open competition prevailed, the pernicious consequences of economic activity would rapidly decrease with its beneficial, pacifying effects quickly rising to prominence.

This distinction is very important to understand the fundamental Smithian beliefs concerning relations between war and not just capitalism, but all of economic life. Obviously, Smith was convinced as to a generalized model based on peaceful competition, erasing violence by suppressing monopoly and sovereignty. Still, even peaceable, orderly, law-abiding economic activities require the existence of rule-of-law; and law, dura lex, by definition implies sovereignty and politics, therefore also violence, although in this case self-restrained violence officially aiming at its own eradication. Indeed, State and sovereignty entail a monopoly on "legitimate violence" (violence recognized as legitimate and exercised within the limits established by written law) in a given territory. A simple but important distinction therefore emerges: "internal trade" versus "international trade"; the first is easier to separate from violence, given the legislating capacity of the state, the second prone to relapse into the condition of a Hobbesian "state of nature."

"Capitalism" was not a term $18^{\text {th }}$ and $19^{\text {th }}$ century authors typically used for economic activities, although they often recognized the importance of "capital" in the sense of lending undertakings producing interest. The $19^{\text {th }}$ century writer who most contributed to the widespread use of the term was probably Karl Marx. For Marx, "capital" (a word that later evolved with other authors into "capitalism") designates not only one specific commercial practice, but a generic set of "production relations" involving the existence of a social group of formally free workers lacking the ownership of the means of production, 
and the owners of those means who hire that workforce and sell the resulting products for profit, thus appropriating the correspondent "surplus value." This relationship, so argued Marx (2012), is normally compatible with peaceful, law-abiding conduct, and really tends to promote this state of affairs, because the functioning of capitalist logic as a whole reproduces itself on a larger scale by ensuring the accumulation of resources on the proprietors' side, which is then reinvested, usually more efficiently (with greater division of labor and more intensive use of machines, for example), providing a greater accumulation of economic surplus, and so on. However, Marx added, underneath the origin of this process lies the usually violent expropriation of workers, who previously were independent owners, being initially separated from the means of production by "non-economic" processes, i.e., direct physical violence. Once this initial phase, or "primitive accumulation," is completed capital is able to follow its logic by resorting only to peaceful, strictly legal means: its beginnings are, however, usually marked by raw violence. The same is valid for international trade, especially colonial trade, a vital cradle of resources obtained via "extra-economic" expedients and then invested in the ordinary process of accumulation, normalizing it in a formally peaceful way.

The difference drawn by Marx between the "primitive" and the "normal" accumulation of capital is retaken, whether explicitly or implicitly, by several other authors. Max Weber (1965) argued that "rational capitalism," supposedly having an "elective affinity" with the Calvinist work-ethic, constitutes a peaceable activity. It is based on work as a profession, diligence and thrift, calculation and a strictly egoistic pursuit of self-interest; but also, and crucially, on recognizing the importance of respect for contracts, the exaltation of predictability, and more broadly, lawfulness and the peaceful nature of business. Weber therefore sharply distinguishes "rational capitalism," presented as a non-intentional ("psychological" rather than logical) result of the Protestant work ethic which later became generalized and is said to define modernity, from other occasional forms of capitalism, and particularly "pirate capitalism," based on plunder and war and therefore more dependent on an acute sense of opportunity and a predatory instinct than on diligence or constant and peaceable activity.

This Weberian distinction reappears, albeit significantly altered, in the work of Sombart (1982), according to whom in the capitalist ethic there was a fundamental defining ambivalence, differentiating and opposing "bourgeois virtues" such as the saving-andinvesting ethos, the exaltation of peaceful and orderly conduct and a quantifying obsession, and an "entrepreneurial" aspect correspondent to combining, unifying and organizing capacities, a sense of opportunity, a killer-instinct, a generic restlessness and appetite for novelty, the inclination to disobey any-and-all commandments and, in this sense, a vague "Faustian" leaning or "longing for infinity." This duality is constant in capitalism's history and, if the "entrepreneurial" trait weakens as a result of bureaucratization, disenchantment and the "iron cage" (the argument is very close to Weber's concerning these features), ecological blockage, declining fertility-rates or any other reason, capitalism in general will be in a very precarious situation. 
The entrepreneurial element is unapologetically predatory and war-inclined: the generic bellicose leaning of societies in which capitalist activities prevail is something that Sombart did not doubt, identifying profit as the main motivation for wars. However, more important, according to Sombart (1943), is the opposite causality, starting from warfare to underline consequently the propitiation of capitalism. More than thinking of war as a consequence of capitalism, it is therefore imperative to understand it as its cause, whether voluntary or involuntary, logically or only "psychologically." Sombart highlights the existence in European armies since the 16th century of a strict unity of command and a rationalization and streamlining of procedures; the ever-increasing need for accurate calculation and rigorous quantification; the extended scale of processes and an élan for unlimited growth, which corresponds both to the long-run tendency of armies and the evolutionary line implicit in the logic of capital; the need for a "domesticated" and disciplined proletariat, to which effect warlike activities are a propaedeutic exercise to the rational industry characterizing modern times. As a matter of fact, in line with Sombart the typical warrior-like virtues (discipline, diligence, patience, persistence, stoicism, bravura in the face of adversity, but also the ability to calculate, a global vision and an acute sense of timing) are virtually the same as the economic virtues, expressing a mix of "bourgeois" and "entrepreneurial" components where the first element predominates at the lower levels of hierarchies and the second obviously at the top. On the other hand, he argues that the organization of armies was the first important sector of social existence where a strict division of labor was imposed en masse and without question. Armed forces were quickly followed by the civilian industries directly producing for them, which were the pioneer sectors of the generalization into "civilian" economic activity of those rationalized standards of conduct. The existence and growth of the armed forces played also a crucial role in the formation of a coherent "consumer-type," standardized and predictable and in a sufficiently high numbers, crucial in generating a global "effectual demand" sufficient to trigger the use of productive resources which would otherwise remain unused.

Sombart's attitude to war, highlighting the importance of demand in the fostering of economic processes, may aptly be called ante litteram "military Keynesianism." It appeals to a consciously demand-side analysis, but focusing on aspects concerning a "warfare state" because it underlines and praises the agonistic, competitive component of consumption and the social inequality inseparable from it, while mainstream Keynesianism developed in the $20^{\text {th }}$ century largely in association with the progresses of the "welfare state" and was predominantly concerned with the reduction of social inequalities. The influence of Sombartian thought in subsequent economic thought, although often denied or repressed, deserves mention also regarding the tradition of "input-output analysis." Actually, he was the thesis-supervisor of Wassily Leontief, whose "input-output matrix," quantifying the impact on the productive sectors of any changes occurring in each of them, constituted an analytical device essential to the development of that field of studies.

Sombart's thesis on a positive correlation between capitalism and war can be opposed to that of Thorstein Veblen (1990; 1994), who contrasted the psychological-cultural element inducing the diligent exercise of professional work with the "sporting instinct," 
explicitly deemed predatory, akin to the desire for ostentation and the corresponding forms of consumption and belligerent initiatives, considered a variety of prowess-cult. For Veblen, however, this second component was supposed to be fundamentally adversary and parasitic on the first. It is therefore a trait recognized as important in actual economic activities, but something to set aside in any alternative economic organization corresponding to what "ought-to-be," and according to Veblen what "can-be." The Sombart-Veblen opposition highlights their different approaches referring to both the warrior element and the "conspicuous" or agonistic trait associated with consumer practices. While these two authors recognize the same fundamental dichotomy in the configuration of modern economic attitudes, according to Veblen the exaltation of luxury and war is fundamentally harmful, while in Sombart's opinion the dynamics of capitalism imposes both elements but is an essentially creative process, although this creation is inseparable from destructive aspects , and may thus be called "creative destruction."

"Creative destruction" is crucial to understand Joseph Schumpeter, whose economic work should be considered as an extended comment on the previous ones. Schumpeter recognizes in "creative destruction" a Janus-like element essential to the study of capitalist economic reality, but refers it as a process of permanent innovation towards greater efficiency characterizing that economy, without relating it to war. This innovation constitutes a form of organization and creation, but it also presupposes a simultaneous destruction and disorganization of the realities subjected to such process. He argues it has a primordial root and an inexhaustible source of vitality in the correlative "heterogony of goals" (Schumpeter, 1976), i.e. the drive for indefinite innovation in patterns of consumption, induced by constant competition with others, or the social compulsion for "keeping up with the Joneses." Schumpeter, however, posited no necessary relationship between capitalism and war; and he also argued for the absence of any link between those two terms regarding the dynamics of imperial expansion and the associated military conflicts. Although imperialism unquestionably produces wars, this is supposedly not the outcome of capitalist logic and actually tends to have conflicting relations with it, given the peaceful penchant which, within a generically "Smithian" argument (see above), Schumpeter $(1986 ; 2009)$ assumes to correspond to the normal exercise of capitalism. Predominantly capitalist societies could thus induce imperial and bellicose tendencies only as a consequence of cultural atavisms expressing the influence of non-capitalist elements.

According to Alexander Gerschenkron (1962), whose ideas were consciously influenced by Schumpeter, economic development processes adopt very diverse characteristics, but can be globally understood considering the timing of each country's development and its relative position. For example, in late $18^{\text {th }}$ century Britain there was a very limited role for banks and a reduced presence of public powers, corresponding to traditional liberalism, i.e., the so-called "night-watchman State" which only guarantees protection in international relations and the rule-of-law internally. The state that Gerschenkron has in mind is therefore predominantly peaceful, and he actually argues that the very concept of "primitive accumulation" is a fundamentally misconceived device, spurious and harmful to scientific research. "Latecomer" countries, however, witness first a systematic 
growth in the intervention of banks, and then a consistent increase in state intervention, imposed inter alia by the progressively enlarged scale of processes. Although starting from very different theoretical assumptions, Gerschenkron thus ultimately accepts the basic correctness of at least a considerable part of Sombart's arguments for the propagation of capitalism by warlike activities. Equally important, he emphasized the importance of proletariat-envy which the Prussian elite maintained during the $19^{\text {th }}$ century, vis-à-vis its British counterpart: the "domesticated" and diligent worker, allegedly typical of the British case, presupposed an educational intervention by armies in previous periods and occurring only later in the Prussian case.

Fernand Braudel $(1977 ; 1984)$ characterized European history of recent centuries by successive cycles of capitalist hegemony, each of them, in its last phase, witnessing the accentuation of capitalist traits. In all cases there was an evolution of social configurations where the relative importance of finance capital and its links with political power increase. These maneuvers may in the short-run enhance prosperity, but the intrinsic tendency of the system towards imbalance is expressed in ever increased militarism. When one hegemony is replaced by another these trends attenuate, capital investment partially returns to productive activities and commercial practices again tend to be based on competition and the open-market, until the cycle returns to the hypertrophy of the financial sector (always an announcer of "autumn," according to Braudel) and bellicosity subsequently recurs. This intrinsic logic of capitalist hegemony-cycles mixes with various dynamics of territorial expansion based on which those cycles are supported and so in turn reinforced.

There is in Braudel's work a distinction between "market," whose meaning is broader and usually associated with open competition, and "capitalism," a stricter category, suggesting links with sovereign powers and the advantages of monopoly, and more prone to war. This distinction evokes the analytical model proposed by Karl Polanyi (2001), whereby all economies operate established on a functional triad composed of "market," "reciprocity" and "redistribution." The first term corresponds to monetary exchanges based on particular interests, the second refers to economic flows of a voluntary, non-egoistic character (such as philanthropy, associations, cooperatives ...) and the third denotes the exercise of sovereignty (taxes, subsidies and state provision of public goods). The normal viability condition of the first component is, so Polanyi argues, that it remains socially "embedded" in such a way that the dynamics of other sectors operate as a counterweight to any possible excessive mercantile component, and compensate for it. According to Polanyi, these devices allowed the 1815-1914 "hundred years' peace," in which the expansion of free-trade on a European scale and the simultaneous prevalence of concord were sustained by the existence of a social network that kept all the European leading circles close, either economically, politically and/or militarily. Inasmuch a full unleashing of the "market" component occurs, though, it evolves into a state witnessing a predominance of strict capitalist relations, driving the social factory to a global situation of imbalance which makes it prone, as a reaction, to autarchic leanings in the economy and to the outbreak of wars. 
The theorizing of Braudel, Marx and others were somehow condensed more recently in the works of Giovanni Arrighi $(1994 ; 2009)$. According to Arrighi, between the $16^{\text {th }}$ and the $19^{\text {th }}$ centuries three successive capitalist cycles occurred-the Genoese-Iberian, Dutch and British hegemonies - each evolving into a terminal crisis including a clear-cut "financialization" of economic activities, the strengthening of the capitalist component and the accentuation of bellicose tendencies. The current period of global economic history is characterized by the hegemony of North-American capitalism, fully accomplished in the $20^{\text {th }}$ century with the demise of USSR and having initiated at the turn of the century a process aiming to create a unified world-state, an intent which came to global failure. According to Arrighi, over the centuries the capitalist dynamics were mingled in various ways with territorial-patrimonial logic, each of these components strengthening the other and, under certain circumstances, the aggressive propensity of the resulting social conglomerate. At the beginning of the 21st century the decline of North-American capitalism's hegemony has been accompanied by the momentous rise of China, corresponding to a form of social organization where capitalist elements are subordinate and interstitial. The predictable triumph of China would be slow, progressive and essentially peaceable, bringing the full emergence and increased global role of the "Third-World" - in broad terms those societies which imperialist European historiography circa 1900 labeled as "peoples without history." In its dying rattle, however, North-American hegemony may either peacefully withdraw and decrease its global involvement, or exacerbate its belligerent inclinations. Given the imbalance of military force on a global scale, hugely favoring the unipolar power of the USA, a very real risk exists of the progression to a widespread and global condition of chaos, with considerable danger of the destruction of sovereign entities ("failed states") which at times are targeted as enemies by the hegemonic power, and a possible increase of the unpredictability and uncertainty of the whole geopolitical system. This evolution towards political disintegration and indeed a worldwide decivilizing process has also been propitiated by recent tendencies for the privatization of war, with its systematic outsourcing to "contractors"; in other words, the submission to a crudely capitalist logic of what even $19^{\text {th }}$ century liberalism considered the holy-of-holies of sovereignty's exercise: police and military roles.

The work of Michael Mann (1986a; 1986b; 2012; 2013a), endowed with a gargantuan theoretical appetite, produced an overview of history conceptualized mostly as evolving forms of social power, referring back to "social caging" processes which fashioned the first important civilizations, and all the way up to the more crucial problems of the present, both theoretically and practically. Mann underlines the manifold character of social power, distinguishing its political, economic, symbolic and military forms, and also the "orthogonal" relations these different axial dimensions have, assuming analytically independent processes of domination/subordination, producing various interspersing combinations through which the diverse dimensions in practical terms intersect and combine, producing huge numbers of possible arrangements. According to Mann, ours are times of a decreasing American hegemony, yet still devoid of any alternative global project viably disputing the dominance of capitalism. As a matter of fact (and well be- 
yond the recession immediately subsequent to the financial crisis of 2008) we may be heading for a long period of economic depression, with zero or very exiguous growth; a "steady state" mostly induced by ecological obstacles, with a lesser unequal distribution of wealth on a global scale thanks to the comparative slow ascent of the Big South countries, more prone to adopt developmental-statist models, and recurrent impasses in richer ones, two social models competing here for predominance: one market-oriented and liable to greater hostility regarding its disenfranchised citizenry, a Morlock-like underclass (within a generalized tendency for the lower groups to encompass roughly $1 / 3$ of the population, a block of higher-plus-middle classes making up the remaining $2 / 3$ ), whereas a social-democratic model is apparently also viable, rather more lenient vis-àvis their own injured and insulted. These occasional social-democratic tendencies are conceptualized by Mann (2013b; see also Mann, Jerónimo, 2013) mostly within a Polanyiinspired frame, various non-mercantile elements of the social fabric compensating for the possibly nefarious influences of unrestrained capitalist markets.

The driving motive for economic development is confined in Mann's diagnosis to the central Schumpeterian theme of "creative destruction," the best of intentions coming down to orient this impetus towards technological innovation, arguably inducing an large environmentally-friendly technological revolution capable of stimulating simultaneously economic growth and ecological beneficence. In parallel, projects to curb the power of global finance ought to be pursued as well. Mann argues that in international policy inter-state conflicts are likely to decline, within a global context where the very importance of the nation-state is supposed to decay, leaning towards global governance, supplemented by the emergence of a truly global civil society and a set of more-or-lessdemocratic institutions proficient in monitoring the political instances endowed with the capacities for this global governance. Mann recognizes the intrinsic need for choices concerning politics, democratic institutions potentially acquiring dimensions directly in conflict with ecological imperatives, the need emerging for centers of political power to face tradeoffs, and sometimes to make agonizing choices. Within this broad theoretical scheme, recent American bursts of "global bully" behavior are interpreted as basically uncoordinated, mostly hubris-induced courses of action, corresponding to an "incoherent" imperialist (Mann, 2005) proclivity that radically departs from any economically sound purpose, instead expressing mostly a "back-seat driver" attitude which hinders both the direct targets of the corresponding military endeavors and any possibly economic consistency regarding US national interest. Things do not seem so amicable in Mann's global scenario, various equilibriums being recognizably unwarranted and the focuses for hostilities assuming multifarious shapes and sizes, with global uncertainty and precariousness about the balances in global systems in part stemming from its own cumulative dimensions of orthogonality, and the correspondent complexity. Mann's verdict is therefore fragmentary at best, the socio-historical Haruspex acknowledged to be better in retrospective exercises, rather than prospectively. 


\section{Some Relevant Facts}

The wars of the last two centuries match a considerable number of aspects of the previously described theoretical schemes, but significantly diverge from them in many others. First of all, Karl Polanyis "hundred years' peace" was an important fact for Western Europe, but only that part of the world. An important exception to it was the FrenchPrussian conflict, inextricably associated with the emergence of Prussia-Germany, seeking continental hegemony and disputing even British global ascendancy. Moreover, Prussian-Austrian clashes, Italian unification conflicts, the Crimean and Balkan wars, Mexican-American hostilities and somewhat latter also the Spanish-American and Russo-Japanese wars clearly indicate that there was not a consistent lessening of tensions, instead they mostly were transferred from a relatively restricted West-European scenario into a globalized one. Actually, the $19^{\text {th }}$ century was a period of very important imperialist expansion, including the "scramble for Africa," central Asia's "Great Game" and numberless other military occurrences more or less directly related to European colonial enterprises and/or American westwards expansion (cf. Davis, 2002; Losurdo, 2011; Lybeck, 2010).

Arguably, Polanyi's basic frame of analysis remains too "Smithian" in the sense of assuming economic prosperity would improve with peace and free-trade, Polanyi essentially hedging this underlying narrative with the important proviso that trading relations ought to be compensated for by adding components of both "reciprocity" and internally robust "redistributive" political institutions. However, protection not free-trade prevailed during the $19^{\text {th }}$ century, besides mostly contributing for increased economic growth regardless of what conventional economic wisdom suggests today (Bairoch, 1999). Protection was also partly the result of rising political participation which culminated in universal male suffrage by the early $20^{\text {th }}$ century in most European societies, and so it may be assumed that the widespread free-trade advocated by Smith would be viable only with the preservation of a mostly aristocratic society, more or less in line with the network of economic-political interests and family ties that Polanyi notes to have de facto dominated Europe prior to 1914.

Is there, in a socially opposite sense, any viable globally peaceful political development accompanied by both political democratization and sustained economic growth? Conversely formulated: does the set of social configurations expressing a "persistence of the old regime" (Mayer, 1981) actually contribute to the preservation of peace, or does it instead foster global aggression inducing warfare? These are still unresolved issues, and particularly relevant ones regarding the debates associated with the commemoration of the centenary of World War I. That the aristocracies of $19^{\text {th }}$ century polities propagated peace holds true for a small European horizon only, since tensions were in fact exported, or transferred outwards with global imperial-colonial expansion. At any rate, these warlike dispositions hence directed outwards were later fundamentally reoriented towards an internecine conflict which evolved into a huge "European civil war," sometimes also called the "second Thirty-Years War," lasting until 1945 (cf. Canfora, 2006a: 152). This was 
due to the close and complex intermingling of multiple inter-state warfare with various social conflicts based on both class and national issues and the correspondent unsettled questions.

One group of participants intensely affected by these conflicts were the various Marxist currents which prior to 1914 had coalesced into an important group of both legal and illegal political parties in the most important countries participating in the conflict. Although Marx had left no single indisputable legacy of ideas concerning war, the political currents so inspired were largely peace-leaning, namely for the crucial reason that Marxists had increasingly become aware of how war efforts were contributing to the desire for internal social peace, thereby preserving and reinforcing the capitalist domination in each of the countries concerned. Moreover, the debates subsequent to the deaths of Marx and Engels, and particularly the ideas expressed by Vladimir Lenin (1999), recognizably under the influence of John Hobson and against the thesis upheld by Karl Kautsky, had underwritten the importance of imperialism as a form of consistently violent conquest of cheaper natural resources and labor, and obtaining markets as a destination for both profitable capital investments and the sale of final products.

As a matter of fact, whereas European powers in this period tended to takeover formally separate colonial regions, with guarantees of the preservation of a "vital space" for free pillage of resources and duly protected final markets for each of the colonial rulers, the USA repeatedly subscribed to "open door" policies which were supposed to avoid the saturation of products for American industries (Williams, 1984). It should be noticed that, given the diversity of geographical conditions, Americans were consistently less worried about the possible scarcity of resources and Malthusian overpopulation fears, recurrent in Western Europe during most of the $19^{\text {th }}$ century. On the other hand, given the industrialist path pursued at least since the Civil War and the recurrence of an industrial overproduction crisis, US leading circles became increasingly concerned with guaranteeing markets for their products under the absence of formal monopolies for any country. This would arguably provide them with the conditions to fully enjoy their underlying advantages, and so they consistently avoided any formal closure of geographic spaces by any other imperial power. This was supposed to promote the smooth replacement of the previous British "imperialism of free-trade" by an American one, with less emphasis on free-trade specifically, but still generically aiming at less impeded international movement of goods and capital flows. William Appleman Williams directly related this broad attitude regarding international relations, one that has come to define the permanent unchangeable bipartisan consensus of the entire North-American political establishment, to an initial "imperial anti-colonialism" which produced an emphatic "turn to imperialism" during the crises of the 189 os (Ibid.: 20-57). It was characterized by a persuasion, stemming from the views of the "frontier-thesis" associated with Jackson Turner, according to whom the combination of prosperity-cum-democracy, defining the American social experiment, could only be maintained if such an indefinitely open "frontier" was artificially maintained, after physical settlement had been accomplished up to the Pacific shore, via 
a fix of external policies warrantying the endless opening of markets for both American products and capital.

American "open door" policies suggest another recurrent theme of discussions within Marxist circles in early $20^{\text {th }}$ century: Karl Kautsky's idea regarding the possible formation of an "ultra-imperialism" (cf. Anderson, 2002) resulting in a condominium of ruling powers exerting dominance over the rest of the world, without any formal colonial empires, and indeed guaranteeing a margin of peaceful economic competition within the "first league" powers; but even more importantly ensuring the permanent exclusion, albeit only factually, of the rest of the world from the ruling clique. Such a scenario had previously been suggested as early as the 1840 s by Friedrich List (2005), who advocated active protection for "infant industries" in countries deemed culturally suitable for industrialization, but simultaneously proposing a global or "cosmopolitan" free-trade arrangement ascribing to what is today called the Big South the mere production of raw materials or the "primary sectors" (agriculture, livestock and mining), whereas only truly culturally fit societies, i.e., Central-Western Europe and Anglo-Saxon America plus likely some marginal areas of European settlement south of Capricorn, would engage advantageously in industrializing endeavors. These were importantly supposed to occur in an environment of fair-play within the "first league" of polities, formal colonial empires having to be discarded and so the possibilities left open for each of the ruling condominium, whose collective permanent global monopoly was buttressed on factual advantages only, not in any written clause formally excluding the rest.

Things do not, however, always occur by the book, a fact easily understood by only briefly considering the cusp of the $19^{\text {th }}$ and $20^{\text {th }}$ centuries: in other terms the last portion of the so-called "Age of Empire," 1875-1914, plus the very beginning of "Age of Extremes" or the "short 20 ${ }^{\text {th }}$ century," 1914-1991 (Hobsbawm, 1989; 1996). Significantly, a number of important declining empires had to be rather proactively helped into actually withering away, mostly swapped by the dominance of the emergent USA or the Western-European powers. This was clearly the case with North-Americans replacing the Spanish Empire in Cuba and the Philippines, yet stopping on the brink of establishing a new formal colonial domination over the natives; it was also the case with the division of remains of the Ottoman Empire, Britain and to a lesser degree France carefully partitioning extended areas of influence but at the same time discretely flirting with emergent Arab nationalisms. The prevalence in these cases of formal "open door" principles did not, however, prevent the Japanese from intensely engaging in a strict imperial-colonial enterprise regarding very large areas in Eastern Asia and the Pacific, nor did it impede both Germany and Italy from entering a furious latecomers race to create formal colonial empires in Africa, these endeavors no doubt contributing for the generic embitterment of conditions which immediately predated World War I.

In Europe, and although facing the seemingly unstoppable global ascent of the USA, the United Kingdom remained during this period the major power and having the biggest colonial empire, in diplomatic terms oscillating between an attitude of "splendid isolation," i.e. the tendency to assume being apart-from-and-above everyone else, and 
a growing inclination to directly intervene in continental Europe and more broadly in world-politics, establishing formal pacts with a number of partners-the Anglo-Japanese alliance enacted in 1902 and Entente Cordiale, with France, in 1904. Within a complex system of enmities and alliances in Europe, the rivalry stands out between France and Germany, unified under the egis of Prussia in the immediate aftermath of victory in the Franco-German war of 1870-1871, resulting in the German annexation of Alsace-Lorraine, a shift in sovereignty which France managed to revert only in 1918. In this context, the Franco-Russian Alliance in 1894, complemented by the Anglo-Russian Entente in 1907, debouched into the advent of a Triple Entente between United Kingdom, France and Russia, this block neatly opposing the Dual Alliance of Prussia/Germany and Austria-Hungary, with the addition of Italy in the Triple Alliance lasting from 1882 to 1914 (when Italy first chose neutrality in World War I only to latter shift into the opposing block).

World-wide though, whether in spite of North-American "open door" policies or thanks to them, the European ascent peaked, with China suffering a full-fledged series of unequal treaties that characterized the "century of humiliation" (1839-1949) and largely transformed into a de facto colonial dependency, in spite of the republican revolution of 1911; the Turkish Ottoman Empire openly recognized as the homme malade or the "sick man" of European politics, dismemberment and a republican revolution occurring in 1918-1922; India reduced to the condition of a formal colony, a situation that would-be pro-independency politicians were by this time unsuccessfully trying to attenuate via an evolution to dominion-status; and the partition of Africa concluded in the final years of $19^{\text {th }}$ century. The most remarkable exception to this trend for European rule was Japanese victory in the Russo-Japanese war of 1904-1905, a fact culturally processed within Europe by symbolically accepting the Japanese as "honorary Europeans" (or "honorary whites," as they were also latter described), while growing doubts were emerging concerning the deep character of Russia: whether truly European or instead fundamentally Asiatic behind a fragile European façade, thus necessarily "despotic" in nature.

Regarding cultural aspects important for World War I, in the West imperialist endeavors had been mostly justified within the ideological ambit of the so-called mission civilisatrice, which European countries claimed to have vis-à-vis non-white peoples (with significant variations, and important doubts regarding the capacities of these peoples to ever really become "educated" or "civilized"). This theme was transferred during the war onto enemies, the Germans becoming its victims, usually assimilated to non-Europeans by the Western Propaganda effort. In a clear-cut contrast, in Germany emphasis was put on Kultur, as opposed to merely material civilization, with specificities and diversity enhanced, uniqueness or the "ineffable individuality" of each society exalted and a broader "ideal" emphasized as opposed to merely material aspects of existence. This rift of ideas was subsequently accentuated by adding "vitalistic" elements, mostly of a Nietzschean variety, producing an intense worship of Schicksal or "destiny," predominantly conceived as a collective destiny within a "popular community" or Volksgemeinschaft: community here representing a traditional, spontaneous, affective, disinterested and all-embracing 
association, as opposed to "society," posited to be historically more recent, grounded on calculation and interest only, affectively cold and life-segmenting. Therefore, in generic terms the war was officially, from the Entente Cordiale perspective, a civilizing enterprise directed against the "Huns," as the Germans were depreciatively called, demoting them from the "noble" part of humankind or that inhabiting the Euro-Atlantic sacred space. Conversely from the German viewpoint it was a war for "community" and an "organic" way-of-life, as opposed to merely "mechanistic" Gesellschaft or "society"; a war for the "ideal" and "collective destiny" against mere materialism and utilitarian individualism; a war of the "metaphysical people" against "positivist" calculating ones; a war of a unique ideal "culture" against grossly material and standardized "civilization" (Elias, 2000; Losurdo, 2001). At any rate, another important element to consider in the preconditions of World War I was the fact that Europe was in 1914, according to Fernand Braudel, politically on the edge of socialism, and so an outer conflagration had to be somehow produced by the elites in order to divert attention from the class conflicts internal to each of the main countries (cf. Canfora, 2006a; 2006b). In this sense this war was "the great class-war" (Pauwels, 2014), one that the various upper layers of society-an amalgam of capitalist cliques and aristocratic groups that had more or less fused with them-had to induce to preserve their privileged positions from the attacks promoted by the diverse political currents disputing it, and apparently with very real chances of success until the war's unleashing.

In the context of the overwhelming war-eulogy that globally characterized this period, one declaration stands out for its pathos and notoriety, fully expressing the German war ideology that officially despised superficial "bourgeois civilization" and longed for a revival of the "tragic culture" supposedly having characterized classical Greece: the one by Max Weber, usually a scholar with moderate political opinions, however on this occasion enthusiastically praising the conflict as a "great and wonderful war," highly promising for a rupture with routine and "mechanistic" ways. Subsequently, in the Weimar period, the German milieu came to produce a variety of thought that was designated as "reactionary modernism," in broad terms intending to retain technical novelties stemming from instrumental rationality, but fusing them with a restored "soul," thereby creating a global "re-spiritualization of technology" (Herf, 1984). Equally important, during the war Germany showed a tendency to turn some of the Entente's motives against it, for example momentarily subscribing the "civilizing mission" theme to stress (in a mood clearly echoing Confederate outrage regarding the Union's appeal to black battalions during American Civil War) that Western Allies were actually using non-white, colonial troops in the European theater, which was supposed to constitute a clear lack of military sportsmanship; analogously, there was an inclination to identify Russia as not a truly European society, rather an Asiatic one under only a feeble "civilized" European mask. This theme was fully developed mostly after the Bolshevik revolution of 1917 and it was destined to have an extremely important role a few decades later: German ruling circles were increasingly prone to consider Russia as nothing but a large space susceptible to colonization, doomed to political dismemberment and subsequent sidelining and absorption, whether 
peaceful or violent, by Central or Western European polities, its native populace mostly destined for subaltern social positions, indeed explicitly assumed as slaves in the case of Nazi ideology (cf. Losurdo, 2001).

A number of other national trajectories and alignments are worth noting, regarding the period subsequent to World War I. The first is the increasingly voluntary submission of the French elites to the German ones, within the ambit of what was called by Annie Lacroix-Riz the "choice of defeat" (2008; 2010b). This was a conscious, premeditated abdication of any relevant initiative, voluntarily ceasing to be a global historical protagonist and deliberately entering a subaltern position vis-à-vis their German counterparts. It occurred within a world-vision according to which France was an essentially "sinful" and "damned" country, with a disastrous global historical path which endlessly had produced revolutionary events and showed no signs of repent, making unviable the secretion of any lasting social cement and therefore somehow deserving a national euthanasia: the cultural baton of longue durée, inextricably associated with the Roman, Frankish and "Western Christian" legacies would thus be transferred to a Greater Germany, actually and symbolically amplified and metaphorically referred to as "Europe." A somewhat analogous process was identified by the same authoress regarding the deep continuities underpinning Vatican policies (2010a), which have repeatedly and consistently marginalized the vital interests of various predominantly catholic countries, such as Poland and France (not to mention an Italy mostly regarded with a mix of suspicion and spite), and reduced Austria to a clearly subaltern position, instead enthusiastically doing all in its power to advance whatever might be considered the interests of "the Reich" even well before 1914, German predominantly protestant leaning and Kulturkampf notwithstanding. The Vatican's basic instinct for Germany qua the alleged representative par excellence of Europe-Christianity was afterwards transported to the other shore of the Atlantic, with the originally mostly protestant and always fiercely "we-firsters" USA becoming the consistent beneficiary of that transfer of devotion.

Such a shift of fundamental loyalties underwrites the possibilities of the occurrence, within large historical periods, of several in-depth realignments. It highlights the importance of economic, and more specifically capitalist motivations for warlike endeavors, but also the presence of various other social components, namely cultural and political traits often operating as mediators in such processes. That is how one specific war may, on occasions, assume the character of a procedure to direct economic advantages, truly becoming a pillaging operation according to the motto of "no-blood-for-oil" recently and famously used by opponents in order to expose and denounce it; but it may also constitute a specifically political maneuver designed mostly to obtain support from the masses via a fundamental redefinition of alliances and oppositions, actually systems of fabrication of both friends and foes. This basic modus operandi was unquestionably applied by European elites during their imperial-colonial expansion, having immediate economic advantages, but even more importantly serving to attenuate internal conflicts and foment a collective perception within which the deep sense of collective belonging to one 
privileged, exceptional, "God-chosen" group transferred into the entire imperial nations a trait formerly characterizing the nobility only.

Analogously, this disposition can be, and was repeatedly, employed in diplomaticmilitary alliances, in the case of Europe quite notably by the USA. These have as early as the 1820 famously asserted against Europe, and especially targeting Britain, their indisputable right to decide as to everything concerning the so-called "Western Hemisphere," i.e., the entire Americas: hence a "West" that did not only exclude Europe, moreover it was directly promoted as a category specifically oriented against Europe. During World War I the American attitude was one of letting the conflicting powers bloody each other first, only to intervene later with a minimum of costs for the USA: hence a position of "splendid isolation" more or less mimicking, but also radically amplifying the model previously used by Britain vis-à-vis continental Europe. After the inter-war period, during which American inclinations oscillated more or less freely between Great Britain and Germany, again intervention in World War II was judiciously timed in order to maximize gains and minimize efforts, after what a more proactive approach was implemented: the USA targeted economic gains via the enhancement of "open door" policies, emphatically complemented with strong Keynesian stimulus ("the Marshall Plan") in order to help the allies and their economic recovery, thereby guaranteeing a sustained expansion of American exports. But these economic components, albeit important, are only one part of the story, the other consisting of the political-cum-diplomatic-cum-military alignments being stimulated via the deliberate advancement of a new common enemy, the Soviet Union, consistently antagonized and basically presented an offer it couldn't refuse, namely being forced into an arms-race it could hardly ever win, considering the astronomically different starting conditions (economically, demographically, militarily) (cf. Pauwels, 2002; Roberts, 2006). Hostility regarding the USSR was however a crucial instrument implicitly aligning and forcing into submission all Europeans, as antagonizing Persia had once been fundamental in order to allow Macedonia from above (and also partly from the outside) to unite Ancients Greeks; and maintaining hostility towards France was instrumental in allowing Prussia the mobilization of a pan-Germanic movement for its own benefit: "keeping the Russians out" was, after 1945, a fundamental tool in the process of the US "keeping down" all the Europeans, west and east.

Besides the continued North-American pursuit of "open door" goals and the convenient diversion maneuver of manufacturing a common enemy in order to line-up and subdue allies, there is another important element in post-1945 western policies vis-à-vis USSR, namely the notion, already promoted in German ruling circles during the Wilhelmine age and subsequently much emphasized through the Nazi period, according to which Russia was somehow the northern homme malade of Europe, destined to political fragmentation as were its former rivals, Turkish and Austro-Hungarian empires, Russia proper having to undergo a process of radical downsizing until susceptible to calm Western absorption, its vast regions a potential reservoir of wealth to be transformed into spoils, its populace undergoing a process of semi-colonial submission and its social creams "westernized" more or less according to the model of most Latin-American 
"comprador" elites. This mental frame replicated an even older meme according to which Russia had always been nothing but a non-European, Asiatic shack barely hiding behind a handful of Germanized, Varangian leaders and a number of institutions only formally coping, indeed feebly aping Western mores.

This brings to the center of the debate the important issues of the scale of political entities and of the alleged "cultural temperament" of populations, as well as the implied political ramifications. If it had not been for the 1917 Bolshevik Revolution, French historian Paul Veyne argued en passant in a 1971 book, Russia would have experienced an evolution likely transforming it into an Eastern-European analogous of Brazil (Veyne, 1984). As noted by Alexander Gerschenkron (see above, cf. also Anderson, 2013), one of the more important triggers for development processes in latecomer countries is the persistent tendency for considerably increased state economic initiative, and also the presence of various "ideological fuels" which often play a crucial role in the mobilization of efforts by larger segments of populations: this had been the case already with economic nationalism in Germany and Saint-Simonian ideas in France, so Gerschenkron argued, and a large-scale historical analysis easily identifies Russian Bolshevism as perfectly suited for that role, given both the greater backwardness of the pre-1917 Russian Empire and the inclination already of late Tsarist economic policies to promote a high degree of direct state-intervention in the economic sphere, definitely anomalous to the usual western criteria. Both the persistent leaning to economic "statism" and the tendency for the invention of "ideological fuels," simultaneously enhancing each country's specificities and assigning it a decisive role in universal history, are traits basically normal and indeed expectable, taking into account the scale of the economic backwardness, the usual trend for its increase as a consequence of various processes of "cumulative circular causation" and the titanic efforts often necessary to revert and overcome such situations.

Within Bolshevik Russia, the revolutionary movement seems to have started from a clearly anti-Russian stand (cf. Smith, 1999), which appears understandable considering that collective movements of mass auto-phobia or self-hatred are an extremely important trait that needs to be taken into account in the cultural characterization of societies undergoing routes of comparative impoverishment and/or political peripherization (as occurred in the late periods of the Russian Empire), but this rapidly evolved into processes configuring the metamorphosis of the previous cultural Russian legacy into an adjourned political gospel presumably able to express the basic content of "Russianism" by translating it into a truly universal message, capable of arousing enthusiastic adhesion Urbi et Orbi. In a more immediate manner, this meant the evolution for an outfit of "affirmative action Empire," as Terry Martin called it (2001), a model to be contrasted with, for example, the "Kemalist" path in Turkey, which would presumably have implied more radical geographical downsizing, but in return meaning a more complete internal cultural homogenization and an easier evolution into the usual strictly "unitarian" notion of nationality. Conversely, the predominance of the principles of "affirmative action" and the trajectory consequently pursued prompted the USSR to become, in the long run, an outstanding inducer of national self-assertion movements on a global scale, which is 
valid both for societies until then submitted to formal colonial domination, such as in Africa, Indochina and India, and also cases corresponding to subaltern positions and merely colonial submission, such as by then occurring in China and to a lesser degree in Latin American countries.

Economic interests were thus inextricably mingled with various cultural and strictly political components in order to induce the conflicts which came to characterize the "Cold War." Regarding this, one aspect worth remembering is the retrospectively defensive character of the Soviet attitude in the European theatre, vividly contrasting, irrespective of the various ideological-propagandistic smokescreens involved, with the endlessly expansionist American stance, or its "Faustian bid" (Gowan, 1999), in economic terms to be understood as pursuant of its consistent "open door," globalist goals. Regardless of various possible questions concerning the predominance of material or symbolic factors, whether on a European or a global scale, the USSR had in the post-1945 period the fundamental purpose of building-up what may be defined as a reverted "cordon sanitaire," in other words guaranteeing that its immediate western neighbors were "friendly" countries, consistently avoiding any possible close repetition of either the immediate post-1917 foreign interventions, the Axis invasion of 1941 or any other analogous scenario. These assertions are not meant to deny that the post-1945 Soviet expansion into Eastern Europe became a noxious fact for these countries, or at least a fact that was perceived as noxious by both the elites and the masses of these societies, although the clichéd notion that they were economically hindered either by pro-Soviet geopolitical alignments or by socialist arrangements within their own economic spheres can also be disputed. As a matter of fact, and as noticed among others by Szelényi, Beckett and King (1994; 2005), well into the 1970 s these societies not only became more prosperous in absolute terms: they even caught up with their Western counterparts, a condition however reversed during the subsequent 1975-1990 period. Be as it may, and regardless of judgments passed on the USSR's absorption of these countries into her own "sphere of influence," the fundamental point to underline here is the defensive, and mostly reluctant Soviet attitude regarding conscious expansion, a fact to be contrasted with North-American "Faustian bid" for endless spreading. ${ }^{1}$ Concomitantly though, the momentum induced by the Chinese civil war and revolution, the correspondent preemptive independence quickly granted by Britain to India and the subsequent global wave of anti-colonial upheavals induced a level of global Soviet initiative considerably higher than the one foreseen by USSR's ruling circles, with many events world-wide forcing their hand (such as Cuba, Angola, Afghanistan) and,

\footnotetext{
1. As to this set of problems, see especially the sub-chapter "The Open Door Policy and the Onset of the Cold War" in Williams (1984: 229-243); cf. also Roberts (2006), particularly Chapter 10, “The Lost Peace: Stalin and the Origins of Cold War" (pp. 296-320), and Chapter 12, "Cold War Confrontations: Stalin Embattled" (pp. 347-371). As to the mostly cautious and defensive Soviet attitude during the inter-war period, and within the context of "triangular politics" involving themselves, the western allies and the Axis powers, see also Roberts (1989). It was only after having been repeatedly deceived, rejected and crossed by western democracies (the Spanish Civil War, Czechoslovakia, Munich, etc.) that the USSR suddenly shifted to an alliance with Nazi Germany in 1939.
} 
independently of the various possible outcomes, exacerbating global conflicts far beyond the level wanted by Moscow.

This mostly defensive Soviet purpose clashed with, and was eventually subdued by a globalist North-American endeavor, but a "statist," and mostly militarily leaning USSR would in any case have been expected, Gerschenkron's considerations on backward countries duly taken into consideration. The same holds, at least partially, for the Soviet tendency to over-invest in the ideology of conflicts, "ideological fuels" permanently at risk of backfiring, and often producing more heat than light. Conversely though, the absence of this statist-cum-military propensity plus ideological over-investment leaning would à la longue induce the disappearance or disintegration of the political commonwealth, a fact eloquently illustrated as a vivid counter-factual the by two-and-a-half decades subsequent to the formal end of the Cold War, with Russia qua Russia or more exactly "incommensurate Russia" (Anderson, 2015) becoming the crux of an apparently unsolvable problem from a Western strategic viewpoint, if nothing else because of the sheer geographic fact of its ostensibly oversized dimension.

Even more important on a worldwide scale is the emergence of China, indirectly and partly a legacy of Russia's process of universalization, via Bolshevism and the Soviet Revolution. Mostly peaceful and strictly economy-inclined until recently, and even allowing for some provisional forms of economic symbiosis with the incumbent power, particularly through China's systematic financing of the USA's colossal external debt, China's emergence will sooner or later tend to conflict with American political and military dominance worldwide. That is besides well perceptible within the context of increased Chinese initiatives in what its leading circles consider an economic, geopolitical and cultural "sphere of influence" in Southeast Asia and the Pacific. Regardless of China's predominantly peaceable penchant and the low profile consciously undertaken by its leaders, Arrighi's ideas relating to one cycle of economic hegemony being replaced by another one must be recalled here, the ruling state being the capitalist USA, whereas the emergent power is an officially mostly non-capitalistic society. This unquestionably adds complexity to the usual narrative of just another capitalist cycle of hegemony replacing an older one, but more importantly it allows for historical narratives now decentered from the customary Western mode, and also from its usually intensely egocentric perspectives, with the correspondent errors of parallax (cf. Blaut, 2000).

\section{Concluding Remarks}

The essential uncertainty of the outcomes of this clash remains, with recent events pointing to a bellicose American response to the Chinese challenge, whereas China has shown itself capable of managing alliances, such as the Shanghai Cooperation Organization and BRICS, within which various forms of self-styled "south-south" cooperation are possible and promising, but the Chinese themselves are not necessarily exempt from possible friction, stemming above all from the potential rivalry between China and India, one that will likely be promoted by North-American influence, particularly via its prevailing 
global influence in matters of "soft power." A number of Michael Mann's suggestions may easily be invoked regarding these themes, above all the prevalence of many possible "orthogonal" conflicts, potentially generating an almost endless set of possibilities regarding factual combinations. However, and in partial contrast to Mann's diagnosis, it should also be noted that:

(a) The range of possible positive contributions for economic growth extend well beyond the meager Schumpeterian "creative destruction." Indeed, this often implies consistently greater state intervention in the economies of latecomer countries, which prevents the cavalier early dismissal of the issue of "socialism" from political debates in the foreseeable future, and will really induce a return to it inasmuch as any "bring-backthe-state" idea remains, an undeniable fact whenever "positive externalities" recurrently emerge in association with increased public economic intervention;

(b) The declining importance of the nation-state is definitely not a generalized fact, the recognized need to curb the power of global finance implying the emphatic return of its relevance. Furthermore, this is the only level where democratic institutions have ever operated in a consistent fashion;

(c) The decline of the nation-state may well be instead taken as a mostly symbolic and performative aspect of the social landscape, still an extremely disturbing one, given that it is associated with the systematic disenfranchisement of large masses in several democratic countries, nothing even remotely similar to a genuine "global civil society" having emerged in the meantime. As a matter of fact, even in the case of regional associations, such as the EU, the transfer of power from nation-states to Brussels/Frankfurt has mostly meant the transformation of regular democratic procedures into farces, "democracy" here nothing but an empty shell, the whole process instead understandable as a soft variety of a "choice of defeat" by the national elites (subjection to Brussels/Frankfurt considered better than having to be responsive vis-à-vis the masses on the national level). This is arguably the quintessential nature of the political choices underlying the recent economic tragedies of countries such as Greece and Portugal;

(d) All political arenas have been until the present time, and are likely to remain, instances of the exercise of choices, some of them agonistic, but there are plenty of reasons to believe that a world-wide configuration of political power being exercised mostly by distributing that resource among various formally equal nation-states, such as posited in the UN Charter, is largely more desirable in terms of democratic content (agenda-building, open discussions on the nature of options, informed choices, etc.), world development and the correspondent ecological implications (regarding which it must be remembered that the economic catching-up of poorer countries has been and still is much less environmentally burdening, in comparative terms and on a "per capita" basis, than the perpetuation of the privileges of the "happy few"), and finally with reference to the theme of warlike tendencies, a field where the preservation of various relative equilibriums remains a generically good recipe for peace, the excessive and imbalanced power of the USA during the last decades having undoubtedly produced further trends of bellicosity. 
Although these correspond to bursts of aggressiveness where often no clear economic purpose is identifiable, Mann's suggestion of a complete analytical severing of military aspects from economic ones might be usefully counter-balanced by meditating Polonius' dictum that "Though this be madness, yet there is method in it." As a matter of fact, this leaning towards chaotic, unreliable behavior may instead be more acutely perceived by confronting it with Arrighi's suggestion of an après-moi-le-déluge pattern of conduct, corresponding to one possible option open to US leading circles when facing the decline of its own global economic hegemony.

\section{Acknowledgments}

The financial support of Fundação para a Ciência e a Tecnologia (FCT), Portugal, within the ambit of Project PEst-OE/SADG/UIo428/2013, is greatly acknowledged.

\section{References}

Anderson P. (2002) Internationalism: A Breviary. New Left Review, no 14, pp. 5-25.

Anderson P. (2013) Lineages of the Absolutist State, London: Verso.

Anderson P. (2015) Incommensurate Russia. New Left Review, no 94, pp. 5-43.

Arrighi G. (1994) The Long Twentieth Century: Money, Power, and the Origins of Our Times, London: Verso.

Arrighi G. (2009) Adam Smith in Beijing: Lineages of the Twenty-First Century, London: Verso.

Bairoch P. (1999) Mythes et Paradoxes de l'Histoire Économique, Paris: La Découverte/ Poche.

Blaut J. M. (2000) Eight Eurocentric Historians, New York: Guilford Press.

Braudel F. (1977) Afterthoughts on Material Civilization and Capitalism, Baltimore: John Hopkins University.

Braudel F. (1984) Civilization and Capitalism, 15th-18th Century, Volume III: The Perspective of the New World, New York: Harper \& Row.

Canfora L. (2006a) Democracy in Europe: A History of an Ideology (transl. S. Jones), Oxford: Blackwell.

Canfora L. (2006b) 1914, Palermo: Sellerio.

Davis M. (2002) Late Victorian Holocausts: El Niño Famines and the Making of the Third World, London: Verso.

Elias N. (2000) The Civilizing Process, Oxford: Blackwell.

Herf J. (1984) Reactionary Modernism: Technology, Culture, and Politics in Weimar and the Third Reich, Cambridge: Cambridge University Press.

Gerschenkron A. (1962) Economic Backwardness in Historical Perspective: A Book of Essays, Cambridge: Belknap Press.

Gowan P. (1999) The Global Gamble: Washington's Faustian Bid for World Dominance, London: Verso. 
Hirschman A. O. (1997) The Passions and the Interests: Political Arguments for Capitalism before Its Triumph, Princeton: Princeton University Press.

Hobsbawm E. (1989) The Age of Empire, 1875-1914, New York: Vintage Books.

Hobsbawm E. (1996) The Age of Extremes: The Short Twentieth Century, 1914-1991, New York: Vintage Books.

King L. P., Szelényi I. (2005) Post-Communist Economic Systems. The Handbook of Economic Sociology (eds. N. J. Smelser, R. Swedberg), Princeton: Russell Sage Foundation, pp. 205-229.

Lacroix-Riz A. (2008) De Munich à Vichy: l’Assassinat de la Troisième République, 19381940, Paris: Armand Colin.

Lacroix-Riz A. (2010a) Le Vatican, l'Europe et le Reich, Paris: Armand Colin.

Lacroix-Riz A. (2010b) Le Choix de la Défaite: Les Élites Françaises dans les Années 193o, Paris: Armand Colin.

Lenin V. I. (1999) Imperialism: The Highest Stage of Capitalism, Sydney: Resistance Books.

List F. (2005) National System of Political Economy, New York: Cosimo.

Losurdo D. (2001) Heidegger and the Ideology of War: Community, Death and the West, Amherst: Humanity Books/Prometheus Books.

Losurdo D. (2011) Liberalism: A Counter-History (transl. G. Elliott), London: Verso.

Lybeck E. R. (2010) The Myth of the Hundred Years' Peace: War in the Nineteenth Century. At War for Peace (ed. M. Forough), Oxford: Inter-disciplinary Press.

Mann M. (1986a) The Sources of Social Power, Volume 1: A History of Power from the Beginning to $A D$ 1760, Cambridge: Cambridge University Press.

Mann M. (1986b) The Sources of Social Power, Volume 2: The Rise of Classes and NationStates, 1760-1914, Cambridge: Cambridge University Press.

Mann M. (2005) Incoherent Empire, London: Verso.

Mann M. (2012) The Sources of Social Power, Volume 3: Global Empires and Revolution, 1890-1945, Cambridge: Cambridge University Press.

Mann M. (2013a) The Sources of Social Power, Volume 4: Globalizations, 1945-2011, Cambridge: Cambridge University Press.

Mann M. (2013b) The End of Capitalism? Análise Social, no 209, pp. 927-945.

Mann M., Jerónimo M. B. (2013) Empires, Globalizations, and Historical Sociology: An Interview with Michael Mann. Análise Social, no 209, pp. 947-952.

Martin T. (2001) The Affirmative Action Empire: Nations and Nationalism in the Soviet Union, 1912-1939, Ithaca: Cornell University Press.

Marx K. (2012) Capital, Volume 1: A Critique of Political Economy (transl. S. Moore, E. Aveling), Dover: Courier Corporation.

Mayer A. J. (1981) The Persistence of the Old Regime: Europe to the Great War, New York: Pantheon Books.

Pauwels J. R. (2002) The Myth of the Good War: America in the Second World War, Toronto: James Lorimer.

Pauwels J. R. (2014) 1914-1918: La Grande Guerre des Classes (trad. F. Degrez), Bruxelles: Aden/L'Imprévu. 
Polanyi K. (2001) The Great Transformation: The Political and Economic Origins of Our Time, Boston: Beacon Press.

Roberts G. (1989) The Unholy Alliance: Stalin's Pact with Hitler, Bloomington: Indiana University Press.

Roberts G. (2006) Stalin's Wars: From World War to Cold War, 1939-1953, New Haven: Yale University Press.

Schumpeter J. (1976) Capitalism, Socialism and Democracy, London: Allen \& Unwin.

Schumpeter J. (1986) History of Economic Analysis, London: Allen \& Unwin.

Schumpeter J. (2009) On Entrepreneurs Innovations, Business Cycles, and the Evolution of Capitalism, New Brunswick: Transaction.

Smith A. (1999) The Wealth of Nations, London: Penguin.

Smith J. (1999) The Bolsheviks and the National Question, 1917-1923, Basingstoke: Palgrave MacMillan.

Sombart W. (1943) Guerra y Capitalismo, Madrid: Galo Sáez.

Sombart W. (1982) El Burgués: Introducción a la Historia Espiritual del Hombre Económico Moderno, Madrid: Alianza.

Szelenyi I., Beckett K., King L. P. (1994) The Socialist Economic System. The Handbook of Economic Sociology (eds. N. J. Smelser, R. Swedberg), Princeton: Princeton University Press, pp. 234-251.

Veblen T. (1990) The Place of Science in Modern Civilization, New Brunswick: Transaction.

Veblen T. (1994) The Theory of the Leisure Class, New York: Dover.

Veyne P. (1984) Writing History: Essay on Epistemology (transl. by M. Moore-Rinvolucri), Middletown: Wesleyan University Press.

Weber M. (1965) The Protestant Ethic and the Spirit of Capitalism (transl. T. Parsons), London: Unwin University Books.

Williams W. A. (1984) The Tragedy of American Diplomacy, New York: W. W. Norton \& Company.

\section{Война и капитализм: о некоторых ключевых теориях и значимых фактах}

\section{Жоао Карлуш Граса}

Профессор Лиссабонской школы экономики и менеджмента, научный сотрудник Исследовательского центра экономической и организационной социологии Лиссабонского университета

Адрес: Rua Miguel Lupi 20, Gabinete 213, 1249-078 Lisbon, Portugal

E-mail: jgraca@iseg.ulisboa.pt 


\section{Puта Гомеш Коррейа}

Научный сотрудник Исследовательского центра экономической и организационной социологии Лиссабонского университета

Адрес: Rua Miguel Lupi 20, Gabinete 213, 1249-078 Lisbon, Portugal

E-mail: ritagomescorreia@yahoo.com

Говоря о «капитализме и войне», следует в первую очередь обратить внимание на важные интеллектуальные традиции, обсуждающие связи между этими двумя терминами радикально противоположными способами. Начиная с эпохи Просвещения, в основных интеллектуальных течениях эти два понятия полагались принципиально антагонистическими. Считалось, что экономические связи должны сдерживать развитие социальных конфликтов и способствовать усилению взаимозависимости, а, следовательно, делать обычаи более цивилизованными и содействовать миру как внутри суверенных единств, так и между ними. Включение подобных представлений в мировоззрение ведет к многочисленным последствиям, однако зачастую эти идеи выражались в форме «долженствований» и не соотносились с фактами реальной жизни. Пример - работы Адама Смита, который полагал, что колониальная торговля является в принципе мирной деятельностью, взаимовыгодной для всех ее участников, но одновременно признавал, что экономическая действительность сильно отличается от такой благостной картины. Подлинные причины этого расхождение не до конца ясны, хотя Смит был склонен возлагать вину на монополии и сращение торговли с заботой о государственном суверенитете, что противоречит модели открытой конкуренции, распространяющей мир. В данной статье мы рассматриваем этот кластер вопросов, анализируя соответствующие идеи ряда значимых социальных теоретиков, включая Адама Смита, Карла Маркса, Макса Вебера, Вернера Зомбарта, Терстена Веблена, Йозефа Шумпетера, Александра Гершенкрона, Карла Поланьи, Фернана Броделя, Джованни Арриги и Майкла Манна. Предлагаемые этими авторами теории так же сопоставляются с историческими фактами и тенденциями, отмеченными в работах других релевантных исследователей, в основном историков. Мы полагаем, что необходимо оставаться открытым к сложной, амбивалентной и неопределенной природе социальной реальности.

Ключевые слова: война, капитализм, циклы гегемонии, плюрализм в социологическом подходе, сложность исторической реальности, оригинальность и преемственность в международных отношениях 